\begin{tabular}{|l|l|l||}
\hline \multicolumn{2}{|c|}{ PublisherInfo } \\
\hline \hline PublisherName & $:$ & BioMed Central \\
\hline \hline PublisherLocation & $:$ & London \\
\hline \hline PublisherImprintName & $:$ & BioMed Central \\
\hline \hline
\end{tabular}

\title{
Plant transcription: it's different
}

\begin{tabular}{||l|l|l||}
\hline \multicolumn{2}{|c||}{ ArticleInfo } \\
\hline \hline ArticleID & $:$ & 3864 \\
\hline \hline ArticleDOI & $:$ & $10.1186 /$ gb-spotlight-20001215-01 \\
\hline \hline ArticleCitationID & $:$ & spotlight-20001215-01 \\
\hline \hline ArticleSequenceNumber & $:$ & 301 \\
\hline \hline ArticleCategory & $:$ & Research news \\
\hline \hline ArticleFirstPage & $:$ & 1 \\
\hline \hline ArticleLastPage & $:$ & 2 \\
\hline \hline & $:$ & RegistrationDate : 2000-12-15 \\
ArticleHistory & $:$ & OnlineDate $: 2000-12-15$ \\
\hline \hline ArticleCopyright & $:$ & BioMed Central Ltd2000 \\
\hline \hline ArticleGrants & $:$ & \\
\hline \hline ArticleContext & $:$ & 130591111 \\
\hline \hline
\end{tabular}


William Wells

Email: wells@biotext.com

In the 15 December Science, Riechmann et al. compare transcriptional regulators from plants (Arabidopsis thaliana), animals (the worm Caenorhabditis elegans and the fly Drosophila melanogaster) and fungi (Saccharomyces cerevisiae). They conclude that new motifs, shuffled motifs, and old motifs put to new uses make plant transcriptional regulation very different from that found in other eukaryotes (Science 2000, 290:2105-2110). Arabidopsis has, by their estimation, 1,533 transcriptional regulators, accounting for approximately $5.9 \%$ of its total number of genes. This is 1.3 times the percentage seen in flies and 1.7 times that in either worms or yeast. Over $25 \%$ of the worm and fly proteins have been characterized genetically, compared to approximately 5\% for Arabidopsis. Some families of factors are present in all but plants, reflecting the hypothesis that animals and fungi are more closely related to each other than to plants. There are some plant-specific families, and some juxtapositions of transcriptional regulatory domains are unique to plants. But more of the diversity arises because plants, animals, and fungi have amplified different families of regulators, and put the same regulators to different uses.

\section{References}

1. Science, [http://www.sciencemag.org/]

This PDF file was created after publication. 